\title{
A Sanskrit Fragment of the Mañjuśrīnāmasamgīti in Uyghur Script
}

\author{
Jens Wilkens ${ }^{*}$ \\ (Göttingen - Germany)
}

Özet: Uygur Alfabesiyle Yazılmış Sanskritçe Mañjuśrīnāmasamgūit Fragmanı Mañjuśrinnāmasamgīti ("Mañjuśrīnnın adlarını zikretme”) adlı Tantra Budizmi eseri, Yuan döneminde (MS 1279-1368) Uygurlar arasında çok popülerdi. Bu çalışma, St. Petersburg Koleksiyonu'ndaki kursiv yazılı bir yazmayı, Uygur harfli mantravinyāsa'nın ("mantra'nın tertibi") - eserin ana ritüel kısmı - Sanskritçe metni olarak tespit eder. Yeni tanımlanan bu parça, Moğol İmparatorluğu döneminde Uygur Budizminin geç evresinde Sanskritçenin önemine bir kez daha tanıklık eder.

Anahtar Kelimeler: Mañjuśrinnāmasamgīti, Eski Uygurca, Sankritçe, Tantrik Budizm, Orta Asya.

\begin{abstract}
The tantric Buddhist work Mañjuśrināmasamgìti ("Chanting of the Names of Mañjuśrī”) was very popular among the Uyghurs during the Yuan period (1279-1368 CE). The article identifies a manuscript in cursive writing from the St. Petersburg Collection as the Sanskrit text of the mantravinyassa ("The arrangement of the mantra") - the core ritual part of the work - in Uyghur script. This newly identified piece testifies once more to the importance of Sanskrit in the late phase of Uyghur Buddhism during Mongol rule. Key Words: Mañjuśrīnāmasaṃgīti, Old Uyghur, Sanskrit, tantric Buddhism, Central Asia.
\end{abstract}

\footnotetext{
* Dr., Göttingen Academy of Sciences and Humanities, Jens.Wilkens@phil.unigoettingen.de, ORCID: 0000-0002-5110-0533.
} 
In the year $1996 \mathrm{~L}$. Yu. Tugusheva published a selection of Old Uyghur manuscripts from the St. Petersburg Branch of the Institute of Oriental Studies. Under text no. 1 (former shelf mark: SI KR I 6; new shelf mark: SI $4131^{1}$ ) in this edition, we find as text B a piece in Uyghur script ${ }^{2}$ of the cursive type in ten lines, which has hitherto eluded identification, ${ }^{3}$ but can now be identified as being a rendering of the Sanskrit Mañjuśrinnammasamgiti ("Chanting of the Names of Mañjuśrî”). ${ }^{4}$ This work, which is also known under the titles Nāmasamgìti and Paramārthanāmasamgīti ${ }^{5}$ is one of the most widespread texts of mature tantric Buddhism or "perhaps the most popular canonical ritual text" of the Vajrayāna in general ${ }^{6}$ with a rich commentarial tradition. ${ }^{7} 167$ verses, mantras, and a prose section make up the basic structure of the text. ${ }^{8}$ The Mañju-

1 I would like to thank P. Zieme for pointing out the new shelf mark of the fragment to me.

2 Tugusheva 1996:8; facsimile on p. 10, Fig. 1 (above).

3 Tugusheva (1996:8) notes that the texts published by her "belong to the marginal area of literature and business".

4 General information is provided in Tribe 2015. The Uyghur version is not mentioned in this article.

5 Tribe 2015:354. The title Nāmasamgīti was used by the Uyghurs as well. Apparently this title was the most common one. It is attested in a letter (spelled namasaygit) in which the famous Anzang (Chinese 安藏 an zang) (†1293 CE) is mentioned as the translator. See Moriyasu 2019:190 (line 18). We find the spelling nama-sayit in the block-print Mainz $305+\mathrm{U} 4134$ line 5 (ed. Kara 1981:230). In a block-printed colophon the title is spelled as nama-sayit (Zieme 1985:179, no. 50:14). The same spelling with a diacritical dot next to the second letter $<\mathrm{n}>$ is found in a colophon to a collection of works (Zieme 1985:165, no. 46:7). In a pilgrim inscription from 莫高 Mogao cave no. 138 the spelling nama-sayit is attested. See Matsui 2017:29 (no. 31:5).

6 Davidson 1981:1.

7 This commentarial tradition starts in the middle of the 8th century. See Tribe 2015:353.

8 Tribe 2015:353. 
śrīnamasamgīti is especially important in Tibetan and Nepalese Buddhism. ${ }^{9}$ Fragments of the Old Uyghur translation were published together with a German translation as text B by Kara and Zieme in 1977 in their joint edition of tantric works. ${ }^{10}$ A few years later G. Kara edited some more pieces which were identified by $P$. Zieme after the edition from 1977 had appeared. ${ }^{11}$ Further newly identified fragments of the Old Uyghur version and of the Sanskrit text in Uyghur script with an interlinear Brāhmī version are mentioned by P. Zieme in his edition of the "magical" texts. ${ }^{12}$ All these pieces are block-printed. P. Zieme could also identify the fragment $\mathrm{Ch} / \mathrm{U} 8021$ (MIK 028476) as a transcription of the Chinese version of this text in Uyghur script. ${ }^{13}$ Further pieces of this type from the collection in St. Petersburg were identified and edited by M. Shōgaito. ${ }^{14}$ A block-printed colophon in strophic alliteration was published by P. Zieme in $1985 .{ }^{15}$ This colophon is particularly significant because it mentions the scholar Karunadaz (Skt. Karunāāāsa) $(\dagger 1311 \mathrm{CE})^{16}$ as the translator of one version of the Old Uyghur Mañjuśrinammasamgitti. The date given for the translation which was made in 大都 Dadu (Great Capital = Beijing) is most likely $1302 \mathrm{CE}^{17}$

After Avalokiteśvara Mañjuśrī, the embodiment of Buddhist wisdom (Skt. prajña $),{ }^{18}$ certainly is the most popular bodhisattva in mainstream Mahāyāna as evidenced, e.g., in the Lotus Sūtra, the Avatamsakasūtra tradition and the Vimalakìrtinirdeśa, esoteric ${ }^{19}$ as

\footnotetext{
${ }^{9}$ Tribe 2015:358.

${ }^{10}$ Kara, Zieme 1977:83-116 ("Nachtrag” on pp. 117-121).

${ }^{11}$ Kara 1981.

${ }^{12}$ Zieme 2005:9.

${ }^{13}$ Zieme 1996.

${ }^{14}$ Shōgaito 2003:5-26 (I owe the reference to P. Zieme).

${ }^{15}$ Zieme 1985:178-179 (no. 50).

${ }^{16}$ For the date of his death see Franke 1996:84.

${ }^{17}$ Franke 1996:83.

${ }^{18}$ But cf. Quinter 2019:591a: "This conventional designation, however, obscures a more multifaceted persona".

19 The bodhisattva was seen as a state-protecting deity in esoteric Buddhism (Quinter 2019:595b).
} 
well as tantric Buddhism among the Uyghurs. The veneration of this bodhisattva in East $^{20}$ and Central Asia ${ }^{21}$ is closely connected with pilgrimage to Mount 五臺 Wutai in China ${ }^{22}$ - a religious concept which spread also to the Uyghurs. ${ }^{23}$

II.

The first line of the new reading presented here gives the transliteration, the second the transcription and the third one the original Sanskrit text. This Sanskrit fragment is one further example of the tendency in the late phase of Uyghur literature to record Sanskrit texts in the Uyghur alphabet. ${ }^{24}$ So far the specimens are all ritualistic in character. The importance of the Sanskrit text of the Mañjuśrīnāmasamgīti in Uyghur Buddhist circles was previously known because of the above-mentioned block-printed Sanskrit text in Uyghur characters with accompanying interlinear text in Brāhmī. A joint Sanskrit-Uyghur edition of the text is mentioned in a colophon to a large collection of Buddhist works. Whether this information refers to the languages or to the alphabets is not sure. ${ }^{25}$

In the manuscript from the St. Petersburg collection, confusion of dentals is rather common, as are prothetic ( $<$ 'yny'n' $>$ for Skt. jūāna) and epenthetic vowels $(<\mathrm{m}$ 'nčwšyry $>$ for Skt. mañjuśrī).

\footnotetext{
${ }^{20}$ For the beginnings of the cult of Mañjuśrī in China see Quinter 2019:591b.

${ }^{21}$ I. Hamar (2019) has recently emphasised the importance of Khotan for the spread of the cult of this particular bodhisattva.

${ }^{22}$ On the connection between the Avatamsakasūtra tradition and Mount Wutai see Quinter 2019:594a.

${ }^{23}$ Kasai 2020. See especially pp. 17-30 for the cult of Mañjuśrī in Uyghur Buddhism. Kasai also discusses the important role of this bodhisattva in pilgrim inscriptions. Studies on the visual materials from the Turfan region are summarized on pp. 17-18, footnote 35. For a study of the wall painting "Mañjuśrī at Mount Wutai" from Bezeklik cave no. 34 (= Grünwedel's numbering 21; = Oldenburg's numbering 27) see Zhang 2016.

${ }^{24}$ See also Hartmann, Wille, Zieme 1996 for a confessional text and the snake charm (text A) in Zieme 1984:428-433.

${ }^{25}$ Zieme 1985:165, no. 46:7.
} 
The letter $<\mathrm{n}>$ may render Skt. $m$, while Skt. $h$ is represented by the letter $<\mathrm{k}\rangle$. The visarga, however, is ignored throughout. The representation of the seed syllables is thus rather inaccurate. The text is a rendering of the mantravinyassa ("The arrangement of the mantra" $\left.{ }^{26}\right)$, thus the most important core ritual part of the litany. It is therefore likely that the text can be considered complete, which is corroborated by the facsimile. The lower right corner of the manuscript has been torn off, however. It is conceivable that the text, which apparently had not been written by a professional scribe, was used as a kind of amulet.

III.

Transliteration and transcription of the text with accompanying Sanskrit verses: ${ }^{27}$

(01) 'wwm s'rv' trm' [ ]/v'p'v' oom sarva-ḍ(a)rma [bava] svabavaoṃ sarvadharmābhāvasvabhāva-

(02) vyšswd' v'čyr' ' ' //k' pyr'kyrdy višuda vačira a a aha pirakirțiviśuddhavajra a ā ạ̣ aḥ prakṛti-

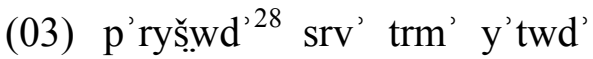
parišuda sarva-ḍ(a)rma yaḍuta pariśuddhāḥ sarvadharmā yad uta

(04) srv' t't'k'd' 'yny'n' k'y' m'nčwšyry s(a)rva-tatagața-iñana-kaya-mančuširisarvatathāgatajñānakāyamañjuśrī-

\footnotetext{
${ }^{26}$ According to Davidson 1981:44, where this part of the text is also translated.

${ }^{27}$ The Sanskrit text follows Davidson 1981:68.

${ }^{28}$ The dots next to the letter $<\breve{\mathbf{S}}>$ are barely visible.
} 
(05) p'ry šwtyd'n 'wp'd' yyty pari-šuḍițan upada-yeti aa-a pariśuddhitām upādāyeti a āḥ

(06) srv' $^{\prime} t^{\prime} t^{\prime} k^{\prime} d^{\prime}$ qrt'y q' q'r q'r' s(a)rva-tatagața-hrḍaya hara hara sarvatathāgatahṛdayaṃ hara hara

(07) 'wwm qwnk qyry p'k'v'n 'yny'n' oom huy hiri bagavan iñanaoṃ hūṃ hrị̣̣ bhagavan jñāna-

(08) mwrty v'k 'yšsvr ' mq̈ ' v'č' s'rv' murti-vag-išv(a)ra m(a)ha-vača sarvamūrttivāgīśvara ${ }^{29}$ mahāvāca sarva-

(09) d'rm' k'k'n 'm'l'30 sw p'ryšwd' darma-gagan-a-mala-su-parišudadharmagaganāmalasupariśuddha-

(10) d'rm' t'dw 'yny'n' k'rp' darma-ḍațu-iñana-garba a dharmadhātujñānagarbha ạ̣̄

I quote R. M. Davidson's translation of the mantravinyāsa: ${ }^{31}$

${ }^{29}$ Davidson 1981:68, footnote 9 (below) mentions emendations by Vira and Minaev mürtte or mürte $e^{\circ}$ respectively.

${ }^{30}$ The hook of the letter $<1>$ was directly attached to the right part of the letter $<\mathrm{m}>$.

${ }^{31}$ Davidson 1981:44. 
"Om, O pure vajra whose proper nature is the nonexistence of all dharmas, a $\bar{a}$ am $a h$ - that is to say, employing the purity of Mañjuśrī, the gnostic body of all Tathāgatas, $a$ ah, bear up, bear up the heart of all Tathāgatas - Oṃ Hūṃ Hrīḥ. O blessed one, O Lord of Speech who is embodied gnosis, with great speech, $\mathrm{O}$ embryo of the gnosis of the dharmadhātu, being very pure and stainless like the spatial field of all dharmas - āh."

Bibliography:

Davidson, Ronald M. (1981): “The Litany of Names of Mañjuśrī. Text and Translation of the Mañjuśriñammasamgīti". Mélanges chinois et bouddhiques [ $=$ Tantric and Taoist Studies in Honour of R. A. Stein edited by Michel Strickmann Vol. 1] 20, 1-69.

Franke, Herbert (1996): “Chinesische Nachrichten über Karunadaz und seine Familie". In: Ronald E. Emmerick, Werner Sundermann, Ingrid Warnke and Peter Zieme (eds.), Turfan, Khotan und Dunhuang: Vorträge der Tagung, Annemarie $v$. Gabain und die Turfanforschung', veranstaltet von der Berlin-Brandenburgischen Akademie der Wissenschaften in Berlin (9.-12. 12. 1994). Berlin: Akademie Verlag (Berichte und Abhandlungen. Sonderband 1), 83-93.

Hamar, Imre (2019): “The Mañjuśrī Cult in Khotan”. Studies in Chinese Religions 5/3-4, 343-352.

Hartmann, Jens-Uwe, Klaus Wille, Peter Zieme (1996): "Indrasenas Beichte". Berliner Indologische Studien 9-10, 203-216.

Kara, Georg (1981): "Weiteres über die uigurische Nāmasamgīti". Altorientalische Forschungen 8, 227-236. 
Kara, Georg, Peter Zieme (1977): Die uigurischen Übersetzungen des Guruyogas "Tiefer Weg" von Sa-skya Pandita und der Mañjuśrīnāmasamgīti. Berlin: Akademie Verlag (Berliner Turfantexte VIII).

Kasai, Yukiyo (2020): “The Bodhisattva Mañjuśrī, Mt. Wutai, and Uyghur Pilgrims”. BuddhistRoad Paper 5.4.

Matsui，Dai (2017)，“敦煌石窟ウイグル語.モンゴル語題記銘文集成 Tonkō sekkutsu uigurugo mongorugo, daiki meibun shūsei / Uighur and Mongolian Wall Inscriptions of the Dunhuang Grottoes". In: Dai Matsui and Shintaro Arakawa (eds.), Tonkō sekkutsu tagengo shiryō shūsei 敦煌石窟多言語資料集成. Multilingual Source Materials of the Dunhuang Grottoes. Tokyo: Tōkyō gaikokugo daigaku Ajia Afurika gengo bunka kenkyūjo, 1-161.

Moriyasu, Takao (2019): Corpus of the Old Uighur Letters from the Eastern Silk Road. Turnhout: Brepols (Berliner Turfantexte XLVI).

Quinter, David (2019): "Mañjuśrī in East Asia". In: Jonathan Silk et al. (eds.), Brill's Encyclopedia of Buddhism. Vol. 2: Lives. Leiden and Boston: Brill, 591-599.

Shōgaito, Masahiro (2003): ロシア所藏ウイグル語文献の研究ウイグル文字表記漢文とウイグル語佛典テキスト Roshia shozo uigurugo bunken no kenkyū: Uiguru monji hyōki kanbun to uigurugo butten tekisuto / Uighur Manuscripts in St. Petersburg: Chinese texts in Uighur Script and Buddhist Uighur Texts. Kyōto: Nakanishi Printing (Studies in Old Eurasian Languages 1).

Tribe, Anthony (2015): "Mañjuśrīnāmasaṃgīti". In: Jonathan Silk et al. (eds.), Brill's Encyclopedia of Buddhism. Vol. 1: Literature and Languages. Leiden and Boston: Brill, 353359. 
Tugusheva, L[ilia] Yu[sufžanovna] (1996): "Early Medieval Records from East Turkestan". Manuscripta Orientalia 2/3 (September 1996), 8-15.

Zhang, Huiming (2016): An Iconographic Study of Pictorial Fragments "Mañjuśrī and his Assistants" from the Bezeklik Caves (Focusing on Ty-776 in the Hermitage Collection). In: I[rina] F[edorovna] Popova (ed.), Sergej Fedorovic Ol'denburg: učenyj i organizator nauki. Moskva: Nauka Vostočnaja Literatura, 379-403.

Zieme, Peter (1984): Indischer Schlangenzauber in uigurischer Überlieferung. In: Louis Ligeti (ed.), Tibetan and Buddhist Studies Commemorating the 200th Anniversary of the Birth of Alexander Csoma de Körös. Budapest: Akadémiai Kiadó (Bibliotheca Orientalis Hungarica XXIX/2), 425-440.

Zieme, Peter (1985): Buddhistische Stabreimdichtungen der Uiguren. Berlin: Akademie Verlag (Berliner Turfantexte XIII).

Zieme, Peter (1996): “A Fragment of the Chinese Mañjuśrināmasamgīti in Uygur Script from Turfan”. 内陸アジア 言語の研究 Nairiku ajia gengo no kenkyū / Studies on the Inner Asian Languages 11, 1-14.

Zieme, Peter (2005): Magische Texte des uigurischen Buddhismus. Turnhout: Brepols (Berliner Turfantexte XXIII). 